\title{
A succinct review on the therapeutic potential and delivery systems of Eugenol
}

\author{
Mohamed S. Eleleemy ${ }^{a *}$, Basma H. Amin ${ }^{b}$, Maha Nasr $^{c}$, Omaima A. Samour $^{c}$ \\ ${ }^{a}$ Department of Pharmaceutics, Egyptian Russian University, Cairo, Egypt \\ ${ }^{\mathrm{b}}$ The Regional Center for Mycology and Biotechnology, Cairo, Egypt \\ ${ }^{\mathrm{c}}$ Department of Pharmaceutics and Industrial Pharmacy, Faculty of Pharmacy, Ain Shams University, Cairo 11566, \\ Egypt
}

\begin{abstract}
Eugenol; a botanical bioactive substance in clove, basil, cinnamon, and nutmeg was reported to exhibit several therapeutic benefits. Eugenia caryophyllata (i.e; clove) is the major natural source of eugenol with about forty-five to ninety percent of its essential oil. WHO recommended eugenol as a safe, non-mutagenic drug; therefore, it has attracted the attention of many scientists. Two main aspects are dealt with in the current review article, the pharmacological potential of eugenol and the innovative novel delivery systems used for enhancing the therapeutic efficacy of eugenol. In the former section, we summarized the therapeutic mechanisms/indications of eugenol, and in the latter section, we reported some nanotechnology-based carriers for the delivery of eugenol. Eugenol exhibits several pharmacological activities as an antioxidant, anti-inflammatory, antibacterial, antifungal, analgesic, anticancer, neuroprotective, antidiabetic, gastroprotective, and antihyperlipidemic. Several studies discussed combining eugenol with natural and synthetic drugs for enhancing their therapeutic effect with minimal side effects. The promising therapeutic activities of eugenol have led to the fabrication of novel eugenol-entrapped nano delivery systems as microemulsions, nanoemulsions, nanocapsules, solid lipid nanoparticles, liposomes, and ethosomes for further augmentation of its therapeutic activities as well exerting a sustained action. In conclusion, this concise review with some selected studies further complements the reports in the literature, stating that eugenol is a valuable compound in terms of its biological activities and that these biological activities can be enhanced by encapsulation in nanocarriers.
\end{abstract}

Keywords: Eugenol; Clove; Antioxidant; Anti-inflammatory; Antibacterial; Antifungal; Nanocarriers.

*Correspondence | Mohamed S. Eleleemy; Department of Pharmaceutics, Egyptian Russian University, Cairo, Egypt.

Email: eleleemy1@yahoo.com

Citation | Eleleemy MS, Amin BH, Nasr M, Samour OA, 2020. A succinct review on the therapeutic potential and delivery systems of Eugenol. Arch Pharm Sci ASU 4(2): 289-310

DOI: $10.21608 /$ aps.2021.50268.1047

Print ISSN: 2356-8380. Online ISSN: 2356-8399.

Received 22 November 2020. Accepted 28 December 2020.

Copyright: ${ }^{{ }^{\circ}} 2020$ Eleleemy et al. This is an open-access article licensed under a Creative Commons Attribution 4.0 International License (CC BY 4.0), which permits unrestricted use, distribution, and reproduction in any medium, provided the original author(s) and source are credited. Published by: Ain Shams University, Faculty of Pharmacy

\section{Introduction}

Eugenol is a phenylpropanoid substance which exhibits certain pharmacological properties including antioxidant [1], anaesthetic [2], neuroprotective [3], hypolipidemic [4] antimicrobial [5], anti-inflammatory [6], antidiabetic [7], and anti-carcinogenic [8] actions. It is found in a substantial amount in many medicinal herbs extracts including cinnamon, basil, and nutmeg.

Eugenol extraction from its containing plants can be achieved by steam distillation. The essential oil is first extracted from the plants and then blended with three percent sodium or potassium hydroxide solution to form a phenolic 
alkali salt. Steam distillation or solvent extraction is then used to separate the insoluble part of the extract. At refrigeration temperature, the residual alkaline solution is acidified followed by TLC, HPLC, or fractional distillation for eugenol liberation [9]. Modern spectroscopic techniques are used to verify the purity of eugenol. There are several techniques for eugenol extraction including solvent extraction [10], hydrodistillation [11], microwave-assisted extraction [12], supercritical carbon dioxide extraction [13], and ultra-sound assisted extraction [14].

Eugenol (Fig. 1) is a clear to faint yellow liquid with a chemical formula of $\left(\mathrm{C}_{10} \mathrm{H}_{12} \mathrm{O}_{2}\right)$ [15]. It is partially miscible with water and highly miscible with organic solvents. It has a molar mass of $\left(164.2 \mathrm{~g} \mathrm{~mol}^{-1}\right)$, a density of (1.067 $\mathrm{g} / \mathrm{cm}^{3}$ ), a melting point of $-7.5^{\circ} \mathrm{C}$, and $\mathrm{pKa}$ of 10.19 at $25{ }^{\circ} \mathrm{C}$. Eugenol is a hydrophobic molecule, so it can easily pass human cells following a passive diffusion mechanism. Eugenol is rapidly absorbed from the intestinal wall, then excreted in the urine in the form of conjugated metabolites as glucuronide and sulfate [16].

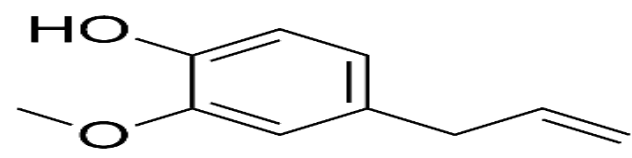

Fig. 1. Structural diagram of Eugenol

\section{Pharmacological potential of Eugenol (Table 1)}

\subsection{Anti-Oxidant Activity}

Diphenyl-1-picrylhydrazyl (DPPH) and 2,2'azino-bis(3-ethylbenzothiazoline-6-sulfonic-acid) (ABTS) assays are the predominant measures for evaluating the antioxidant activity of substances. Eugenol demonstrated (DPPH) scavenging activity as it was able to effectively remove the DPPH radicals. Similarly, Kim et al. [17] stated that eugenol inhibited ABTS and DPPH free radicals in L-ascorbic acid. Thus, eugenol could be stated as a protecting agent against oxidative stress [18]. In contrast, high concentrations of eugenol act as pro-oxidant, which leads to damage of tissues as a consequence of the increased free radicals generation [9].

\subsection{Anticancer Activity}

Eugenol showed promising potential in the prophylaxis and treatment of cervical, gastric, prostate, leukemia, lymphoma, and skin cancers. Hussain et al. [19] tested the effect of combining eugenol with gemcitabine on the cell viability of HeLa cells (i.e. cervical cancer cell line). They found that this combination could inhibit cancer cell growth, even in low concentrations. Also, eugenol decreased the harmful effect of gemcitabine on normal cells. Furthermore, eugenol hindered the apoptosis of Cyclooxygenase-2 (COX-2), B-cell lymphoma-2, and interleukin-1 $\beta \quad$ (IL-1 $\beta)$, decreased inflammation and increased the efficacy of gemcitabine [20]. Manikandan et al. [21] studied the potential of eugenol on gastric cancer induced by $\mathrm{N}$-methyl-N'-nitryl-N-nitrosoguanidine in Wistar rats, and they found that eugenol inhibited cancer cell invasion and angiogenesis by Bcl-2 protein family regulation, cytochrome $\mathrm{C}$, apoptotic protease activating factor-1, and cysteine aspartic protease. Eugenol also changed the activity of mesenchymal metalloprotease, and the expression of Matrix Metalloproteinase-2 (MMP-2), Matrix Metalloproteinase-9 (MMP9)[22], vascular endothelial growth factor, and tissue metalloprotease inhibitor (TIMP-2). Also, Rita et al. [23] investigated the curative action of the combination of eugenol and 2methoxyestradiol on non-androgen-dependent prostate malignancy. They found that this combination could therapeutically suppress the 
propagation of prostate cancer cells. Moreover, eugenol showed promising treatment potential in skin cancer and melanoma [24]. In this regard, eugenol inhibited the propagation of melanoma cells and caused a substantial delay in tumor development [9].

Furthermore, eugenol induced DNA fragmentation when incubated with HL-60 (i.e. leukemia cell line) by induction of reactive oxygen species, inducing mitochondrial permeability transition, and reducing antiapoptotic protein BCL-2 level and release of cytochrome $\mathrm{c}$ to the cytosol, hence resulting in subsequent apoptosis [8]. Cisplatin drug resistance was also combated through its combination with eugenol. This combination triggered the inhibition of breast malignant stem cells by hindering aldehyde dehydrogenase (ALDH) enzyme activity and ALDH-positive tumor-initiating cells [25]. Finally, treatment with eugenol inhibited MMP-2 expression in cells of lung cancer [26].

\subsection{Antifungal Activity}

Eugenol was shown to prevent and treat vaginal and oral candidal infection in immunodeficient experimental rats [27]. Another study confirmed the anti-candidal effect of eugenol with minimum inhibitory concentration MIC (7.5 $\mu \mathrm{L} / \mathrm{mL})$ [28]. Eugenol prompted a marked change in the cell membrane morphology of the fungal species by interfering with adhesiveness and causing a transition to the hyphal form thereby reducing the ability of Candida to colonize the host tissues [29]. Assessment of the antifungal potential of eugenol on Candida albicans showed that eugenol was able to combat $99.9 \%$ of fungal cells within 7 minutes of exposure. The lipophilicity of eugenol improves its flow within the fatty acyl chains of cell membranes, thereby disrupting envelope morphogenesis and cell growth [9] and causing a considerable diminution in the ergosterol amount that is responsible for keeping fungal cell integrity and function. This affects the integrity of the membrane and causes cell cycle arrest [30]. Worthy to note is that methylation of eugenol was stated to increase its antifungal effect [31].

Furthermore, eugenol demonstrated toxicity on several mycotoxigenic fungi like Fusarium [32], Aspergillus, Penicillium, and Alternaria alternate species. Eugenol was also reported to exhibit an antifungal effect against Aspergillus ochraceus, Fusarium graminearum, Fusarium moniliforme, Penicillium citrinum, Penicillium viridicatum, Trichophyton rubrum, Trichophyton mentagrophytes, Candida tropicalis, and Candida krusei [33]. Eugenol showed more antiaflatoxigenic and antifungal action than some synthetic antifungal agents and illustrated broad fungi toxic activity against Botryodiplodia theobromae, Cladosporium herbarum, Colletotrichum gloeosporioides, Aspergillus species [9]. Skin lesions, which are provoked due to Microsporum gypseum, were found to improve within the first week of eugenol application [34].

The antigonorrheal activity of eugenol was also displayed in many multi-resistant Neisseria gonorrhea strains. Noteworthy, eugenol showed marked activity against fluconazole-resistant Candida dubliniensis without provoking hemolytic activity in human erythrocytes [35].

\subsection{Antibacterial Activity}

Eugenol showed strong antibacterial activity against several Gram-positive strains (Enterococcus faecalis [36], Staphylococcus epidemics [37], MRSA, MSSA [38], Streptococcus pyogenes, Streptococcus pneumonia, Bacillus cereus, Listeria monocytogenes, Bacillus subtilis [39]), Gram-negative (Pseudomonas aeruginosa, Salmonella choleraesuis, E. coli, Helicobacter pylori, Proteus vulgaris, Salmonella typhi [40], and Yersinia enterocolitica) bacteria [16], 
anaerobic (oral periodontal pathogen Porphyromonas gingivalis [41]) bacteria, Mycobacterium tuberculosis [42], and Propionibacterium acnes [43].

The phenolic group is responsible for the antibacterial potential of eugenol, even when diluted more than two thousand times. Eugenol causes cell wall degradation of the bacteria, damaging of the plasma membrane and membrane proteins, with exposure of cellular contents and coagulation of cytoplasm [44]. The eugenol hydrophobicity modulates the fatty acid sequence of different bacteria [45]. This property of eugenol could segregate the cell membrane lipids, hence changing its structure to increase the penetrability of the cell membrane.

\subsection{Antiparasitic Activity}

Eugenol exhibited therapeutic potential versus the chloroquine-resistant strain Plasmodium falciparum [46] (causative organism of Malaria disease), and Caenorhabditis elegans [47]. Morphological variations were noted in Leishmania amazonensis and L.donovani parasites, which cause leishmaniasis disease, after treatment with eugenol [48]. Mitochondrial variations occurred at the ultra-structural level, with remarkable swelling, inner membrane disorganization, and an increase in the cristae number [9].

Eugenol also showed anti-insect action caused by its phenolic hydroxyl radical. Eugenol inhibited Haemonchus contortus, as elucidated by the ovum hatching test [49]. Eugenol also reduced the trophosome adhesiveness of Giardia lamblia after being administered for three hours. Eugenol could also be regarded as a promising drug to hinder giardiasis and verminous. Eugenol also caused death or repellent action of the beetle of red flour and males of citrus fruit fly [24]. Eugenol had also a considerable anthelminthic activity on Schistosoma mansoni infection compared to the effect of Praziquantel [50].

\subsection{Antiviral Activity}

Eugenol was tested for its antiviral activity against the herpes simplex-1 (HSV-1) and HSV-2 viruses. The viral replication was down-regulated with eugenol, which reduced keratitis induced by herpes virus in mice [9]. Eugenol inhibited the lipid peroxidation and viral replication of either DNA or RNA virus. In a similar mechanism to antibacterial and antifungal action, eugenol exerts its antiviral activity by disturbing the viral lipidic envelope [51]. Some studies revealed that eugenol induced glutathione S- transferase (GST) in rat liver, which in turn inhibited the replication of HSV-I [52]. The pathogenicity of the Ebola virus could be suppressed by eugenol [53] Moreover, eugenol inhibits the influenza-A virus's replication and autophagy; by inhibiting the initiation of IkB kinase enzyme and extracellular signal-regulated kinase (ERK), and other inflammatory signal pathways [16].

\subsection{Anti-Inflammatory Activity}

Eugenol exhibited powerful down-regulating actions on 5-lipoxygenase enzyme (5-LOX)[9], interleukin-6 (IL-6) production, cyclooxygenase2 (COX-2), and $\mathrm{PGE}_{2}$ production enzymes[18]; all of which are inflammatory mediators provoked during the inflammation process. Additionally, the nuclear factor kappa B (NFKB) inflammatory pathway could be strongly suppressed by eugenol [54]. In another report, the hindrance of prostaglandin $\mathrm{H}$ synthase activity was achieved by eugenol which competitively inhibited arachidonic acid [55].

Moreover, eugenol hindered the cytokines level such as tumor necrosing factor- $\alpha$ and $\beta$ (TNF- $\alpha, \beta$ ), interferon-gamma in the arthritic knee and ankle joints. As a result, eugenol can be considered a promising supplement in the control of arthritis [56].

Additionally, eugenol administration inhibited 
eosinophilia that is induced by ovalbumin in the lung tissue, prevented the increase of interleukin4 (IL-4) and interleukin-5 (IL-5) levels, and reduced the NF- $\kappa \mathrm{B}$ signalizing pathways, resulting in the decrease of airway resistance (AWR). Conclusively, eugenol could be a good therapeutic candidate in asthmatic patients [57].

Eugenol was also reported to increase the catalase (CAT), glutathione-S-transferase (GST), superoxide dismutase (SOD), and glutathione peroxidase (GPx), which are important enzymes combating oxidative stress [58]. On the other hand, several authors [59] performed a study revealing that eugenol stopped the inflammation, and inhibited myeloperoxidase (MPO) activity, malondialdehyde (MDA), NF- $\kappa \mathrm{B}$ expression, TNF- $\alpha$ levels, and oxidative markers. As a result, eugenol reduced hepatic injury by alteration of reduction-oxidation status and inhibition of inflammatory mediators [18].

\subsection{Analgesic Activity}

Eugenol is globally utilized due to its ability to cure dental pain, as eugenol appears to have an agonist effect on $\gamma$-aminobutyric acid (GABA) and an antagonist effect on N-methyl-D-aspartate (NMDA) glutamate receptors which play important role in pain transmission [52].

Eugenol shows a promising analgesic potential in the inflammatory phase more than the neurogenic phase [60]. Lee et al. [61] proved that eugenol suppressed high-voltage-activated $\mathrm{Ca}^{2+}$ channel (HVACC) currents in primary afferent neurons of teeth, so it enhanced the analgesic effect [9]. Eugenol also exerted antipyretic activity when administered by intravenous and intragastric means in rabbits, with a mechanism similar to acetaminophen in the treatment of fever [56].

\subsection{Antidiabetic activity}

Eugenol is a valuable drug in lowering blood glucose levels [62]. Srinivasan et al. [16] evaluated the functionality of the main enzymes accompanying glucose metabolism to assess the eugenol hypoglycemic activity in streptozotocininduced male diabetic rats. Results showed an elevation in hepatic glycogen levels following oral administration of eugenol, hence confirming its anti-hyperglycemic action in diabetic rats. Eugenol substantially restored the reduced levels of glutathione and insulin, enhanced the sensitivity of insulin, and stimulated the glucose uptake by skeletal muscles via activation of the glucose transporter-4 and AMP-activated protein kinase signaling pathway. Based on the aforementioned, eugenol was considered as an ideal therapeutic candidate to cure type 2 diabetes [7]. In vitro eugenol studies revealed its strong binding affinity to the $\varepsilon$-amine group on lysine amino acid, which resulted in a marked reduction of advanced glycation end products (AGEs). Furthermore, eugenol presented $\alpha$-glucosidase inhibition resulting in serum glucose levels reduction without changing the glycated hemoglobin levels. Conclusively, eugenol exhibits antidiabetic activity by two mechanisms; lowering blood glucose levels and preventing AGE formation, hence delineating itself as an optimal agent for the management of diabetes [63].

\subsection{Anesthetic activity}

A single-blind, randomized study was conducted to assess the topical anesthetic activity of clove oil compared to benzocaine. Results revealed indifferent activity between the pain scores of clove gel and benzocaine groups [64] However, it is not advisable to use eugenol as an intravenous anesthetic except in the high incidence of venous thrombosis development around the injection site. The possible eugenol use as a local anesthetic was also confirmed by Park and coworkers [65]. Moreira-Lobo et al. [66] studied the use of eugenol for the mouse 
sciatic nerve excitability. They reported that eugenol inhibited Nat-dependent channel receptor, activated transient receptor potential vanilloid receptor 1 (TRPV1), and hindered the sodium ions flow, accordingly it blocked nerve conduction and decreased the conduction rate. Low eugenol amount was also found to block complex action potential and decrease nerve excitability [24].

\subsection{The central and neuroprotective action}

By combating neuronal complications and inhibiting sciatic nerve transmission, eugenol serves as a neuroprotective drug against amyloid $\beta$ peptides, ischemia, and excitotoxicity [67]. In vitro studies reported eugenol's inhibitory effect on 5-lipoxygenase, with the improvement of neuronal cell damage. Also, eugenol significantly inhibited lipid peroxidation and increased dopamine in experimental rats [68]. Prasad and
Muralidhara [69] investigated the neuroprotective potential of eugenol versus neuropathy induced by acrylamide and concluded that eugenol decreased markers of oxidative stress and suppressed the acetylcholinesterase activity. Conclusively, eugenol could curtail acrylamide induced neuropathy [70].

Garbage et al. [71] also stated that eugenol improved serotonin (5-HT) levels in all CNS regions, with reduction of norepinephrine in all regions of CNS except for the hippocampus. Eugenol exerted its action through the regulation of brain monoaminergic and hypothalamicpituitary-adrenal systems. Consequently, eugenol is considered neuroprotective therapy in stressrelated diseases [16]. Mahapatra et al. [72] studied eugenol's in vitro protective action against cellular damage in rats triggered by nicotine and concluded that eugenol suppressed the cellular damage caused by nicotine

Table 1. Therapeutic potential of eugenol, and the corresponding biological mechanism in the human body

\begin{tabular}{|c|c|c|c|}
\hline $\begin{array}{l}\text { Therapeutic } \\
\text { activity }\end{array}$ & Mechanism & Results delineated from the study & Ref. \\
\hline Antioxidant & $\begin{array}{l}\text { - Prevents the generation of reactive oxygen species \& } \\
\text { reactive nitrogen species } \\
\text { - Exhibits suppressive effect on lipid peroxidation }\end{array}$ & $\begin{array}{l}\text { Eugenol could be used for the treatment of many } \\
\text { cardiovascular diseases (e.g, Atherosclerosis, } \\
\text { Coronary artery diseases), central nervous system } \\
\text { disorders (e.g; Alzeheimer disease, Parkinson's } \\
\text { disease), and skin diseases (e.g; Skin aging, skin } \\
\text { cancer) }\end{array}$ & $\begin{array}{c}{[17]} \\
{[18],} \\
{[9]}\end{array}$ \\
\hline Anticancer & $\begin{array}{l}\text { - Triggers cell apoptosis } \\
\text { - Inhibits prostaglandin E2 production } \\
\text { - Reduces DNA oxidation } \\
\text { - Inhibits matrix metalloproteinases activity (MMP-2, } \\
\text { MMP-9) } \\
\text { - Suppresses COX-2 gene in human colon cells } \\
\text { - Inactivates ERK proteins/pathways } \\
\text { - Inhibits cancer cell invasion and angiogenesis by Bcl-2 } \\
\text { protein family regulation, cytochrome C, apoptotic protease } \\
\text { activating factor-1, and cysteine aspartic protease. } \\
\text { - Blocks vascular endothelial growth factor, and tissue } \\
\text { metalloprotease inhibitor (TIMP-2). } \\
\text { - Inhibits the propagation of cancer cells and causes a } \\
\text { substantial delay in tumor development. } \\
\text { - Induces DNA fragmentation when incubated with cancer } \\
\text { cells by induction of reactive oxygen species, and inducing } \\
\text { mitochondrial permeability transition. } \\
\text { - Inhibits malignant stem cells by hindering aldehyde }\end{array}$ & $\begin{array}{l}\text { Eugenol could be used for the treatment of } \\
\text { malignancy in different areas in the human body } \\
\text { including the colon, lung, skin, and blood vessels. }\end{array}$ & $\begin{array}{c}{[8],} \\
{[9],} \\
{[19],} \\
{[20],} \\
{[21],} \\
{[22],} \\
{[23],} \\
{[24],} \\
{[25],} \\
{[26]}\end{array}$ \\
\hline
\end{tabular}


dehydrogenase (ALDH) enzyme activity.

\section{Antifungal}

- Prompts a marked change in the cell membrane morphology by interfering with adhesiveness, and causing a transition to the hyphal form of the fungal species.

- The lipophilicity of eugenol improves its flow within the fatty acyl chains of cell membranes.

- Disrupts cell wall morphogenesis and cell growth

- Causes diminution in the ergosterol amount that is responsible for keeping fungal cell integrity and function.

- Causes cell cycle arrest.

Antibacterial

Antiparasitic

Antiviral
- The phenolic group is responsible for the antibacterial potential of eugenol, even when diluted more than two thousand times.

- Causes cell wall degradation of the bacteria, and membrane proteins, with exposure of cellular contents and coagulation of cytoplasm.

- Modulates the fatty acid sequence of different bacteria.

- Segregates the cell membrane lipids, hence changing their structure to increase the penetrability of the cell membrane.

- Mitochondrial variations occurring at the ultra-structural level, with remarkable swelling, inner membrane disorganization, and an increase in the cristae number.

- It Shows anti-insect action caused by its phenolic hydroxyl radical.

- Reduces trophosome adhesiveness of Giardia lamblia after being administered by three hours.

- Causes death of repellent action of the beetle of red flour and males of a citrus fruit fly.

- The viral replication is down-regulated with eugenol, which reduced keratitis induced by the herpes virus in mice.

- Inhibits the lipid peroxidation and viral replication of either DNA or RNA virus.

- Disturbs the viral lipidic envelope.

- Induces glutathione S- transferase

- Inhibits viral replication of HSV-I.

- Inhibits influenza-A virus's replication and autophagy; by inhibiting the initiation of IkB kinase enzyme and extracellular signal-regulated kinase (ERK), and other inflammatory signal pathways.
Eugenol could be used in the management of fungal disease caused by Candida, Aspergillus, Fusarium, Penicillium, and Trichophyton species. Also, in the treatment of gonorrhea (i.e; caused by Neisseria gonorrhea )

[27],

[28],

[29],

[30],

[31],

[32],

[33],

[34],

[35]

Eugenol exhibits antibacterial activity against several Gram-positive strains (e.g; Enterococcus faecalis, Staphylococcus epidermidis, MRSA, MSSA, Streptococcus pyogenes, Streptococcus pneumonia, Bacillus cereus, Listeria monocytogenes, and Bacillus subtilis),

Gram-negative bacteria (e.g; Pseudomonas aeruginosa, Salmonella choleraesuis, E. coli, Helicobacter pylori, Proteus vulgaris, Salmonella typhi, and Yersinia enterocolitica), anaerobic (oral periodontal pathogen Porphyromonas gingivalis) bacteria, Mycobacterium tuberculosis, and Propionibacterium acnes

[16],

[36],

[37],

[38],

[39],

[40],

[42],

[43],

[44],

Eugenol could be used in the treatment of malaria, leishmaniasis, giardiasis, verminosis, and bilharziasis.

[9],

[24],

[46],

[47],

[48],

[49],

[50]

Eugenol could be used in the treatment of herpes disease, keratitis, influenza, and Ebola virus disease.

[9],

[16],

[51],

[52], 
Anti-

inflammatory
- Decreases 5-lipoxygenase enzyme (5-LOX), interleukin6 (IL-6) production, cyclooxygenase-2 (COX-2), and $\mathrm{PGE}_{2}$ production enzymes.

- Suppresses nuclear factor kappa B (NF-KB) inflammatory pathway.

- Hinders prostaglandin H synthase activity which competitively inhibited arachidonic acid.

- Inhibits the cytokines level such as tumor necrosing factor- $\alpha$ and $\beta$ (TNF- $\alpha, \beta)$, interferon-gamma.

- Inhibits eosinophilia that is induced by ovalbumin.

- Downregulates interleukin-4 (IL-4) and interleukin-5 (IL5) levels.

- Increases the catalase (CAT), glutathione-S-transferase (GST), superoxide dismutase (SOD), and glutathione peroxidase (GPx), which are important enzymes combating oxidative stress.

- Inhibits myeloperoxidase (MPO) activity, malondialdehyde (MDA) oxidative markers.

- Induced alteration of reduction-oxidation status.

Analgesic

Antidiabetic

Anesthetic

- Potentiates effect on $\gamma$-aminobutyric acid (GABA).

- Exerts antagonistic effect on N-methyl-D-aspartate (NMDA) glutamate receptors which play important role in pain transmission.

- Suppresses high-voltage-activated $\mathrm{Ca}^{2+}$ channel (HVACC) currents in primary afferent neurons of teeth

- Exerts antipyretic activity with a mechanism similar to acetaminophen in the treatment of fever.

- Increases hepatic glycogen levels.

- Restores the reduced levels of glutathione and insulin.

- Enhances the sensitivity of insulin.

- Stimulates the glucose uptake by skeletal muscles

- Activates the glucose transporter-4 and AMP-activated protein kinase signaling pathway.

- Exhibits strong binding affinity to the $\varepsilon$-amine group on lysine amino acid.

- Reduces advanced glycation end products (AGEs).

- Inhibits $\alpha$-glucosidase resulting in serum glucose levels reduction without changing the glycated hemoglobin levels.

- Inhibits Na+-dependent channel receptor.
Eugenol could be used in the treatment of arthritis and asthma.

[9],

[18],

[54],

[55],

[56],

[57],

[58],

[59]

Eugenol could be used for the management of dental

[9], pain and fever.

- Activates transient receptor potential vanilloid receptor 1 (TRPV1).

Eugenol could be used in the management of type 2

[7], diabetes mellitus.

- Hinders the sodium ions flow.

[64],

- Blocks nerve conduction and decrease the conduction rate.

- Blocks complex action potential and decrease nerve excitability. 


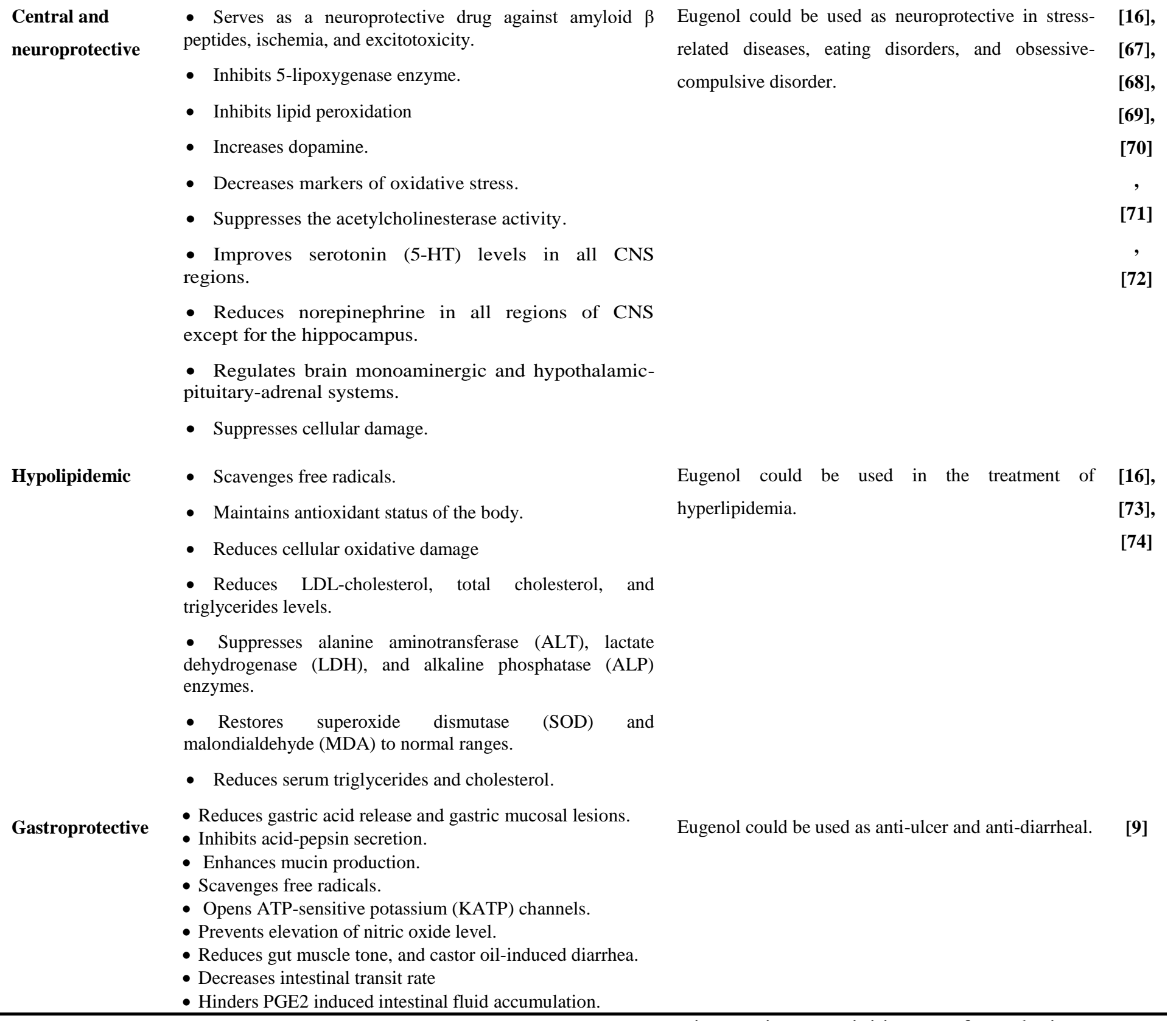

\subsection{Hypolipidemic activity}

Venkadeswaran et al. [73] conducted a study on hyperlipidemia in Wister male mice to evaluate eugenol's anti-hyperlipidemic activity. Administration of eugenol reduced LDLcholesterol, total cholesterol, and triglycerides levels. Moreover, hypercholesterolemic rats administered eugenol exhibited marked suppression in activities of alanine aminotransferase, lactate dehydrogenase (LDH), and alkaline phosphatase (ALP) enzymes. Munisa et al. [74] also showed that eugenol significantly restored the levels of superoxide dismutase and malondialdehyde (MDA) to normal ranges. Similarly, Jin and Cho also tested the hypocholesterolemic action of eugenol in the hyperlipidemic zebrafish model, in which it was 
concluded that eugenol reduced serum triglycerides and cholesterol, therefore it could be sought as a hypolipidemic agent [16].

\subsection{Gastroprotective activity}

It was found that pretreatment with eugenol for one hour reduced gastric acid release and gastric mucosal lesions, resulting in a gastroprotective efficacy in mice with ulcers triggered by indomethacin. Eugenol exerts an anti-ulcer mechanism by inhibiting acid-pepsin secretion, enhancing mucin production, scavenging free radicals, opening ATP-sensitive potassium (KATP) channels, and prevention of the toxic elevation of nitric oxide level. An in vivo study conducted on rats revealed that eugenol reduced the isolated myometrium and gut muscle tone, castor oil-induced diarrhea, intestinal transit rate, and PGE2 induced intestinal fluid accumulation [9].

\section{Novel Eugenol Delivery Systems (Table 2)}

From the aforementioned information, eugenol is reported to exhibit many medicinal and therapeutic actions, especially as an antimicrobial and antioxidant agent. However, since it is easily degraded due to hazardous environmental conditions such as temperature, oxidation, and light, and humidity [75], several nanocarriers have been reported for eugenol. The main purpose of nanocarriers design was to control it's in vivo release, improve its physical stability, protect it from the interactions with the external environmental hazard, minimize its volatility, enhance its bioactivity, reduce its toxicity, and enhance patient compliance and convenience. Encapsulation of eugenol in nanoscale particles is a strategy to solve these issues. Besides, they can also increase the mechanisms of cell absorption and increase bio-efficacy due to their subcellular size [76].

\subsection{Microemulsions}

Microemulsions are nano-based carriers consisting of oil, water, surfactants, and cosurfactants. Eugenol was formulated as waterbased microemulsion systems. Different masses of the eugenol and oil were incorporated in the tween-20 micellar solution by using the oil titration method. The antioxidant and antimicrobial efficacy was assessed using the DPPH assay and the agar disc dilution method, respectively. Diameter of inhibition zones were measured for all concentrations of eugenol and clove oil used (i.e; 0.6, 0.7, 0.8, 0.9\%). It was found that all concentrations of eugenol microemulsions imparted greater inhibition zone diameters than corresponding crude counterparts, especially at the highest concentration (i.e; 0.9\%) which was found to be $(13.6 \pm 1.1 \mathrm{~mm})$ and $(11.8 \pm 2.05 \mathrm{~mm})$ in the case of eugenol and clove oil microemulsion, respectively. Also, DPPH results revealed that eugenol microemulsion exhibited better antioxidant activity than essential oil microemulsion at all concentrations especially at the highest proportion $(0.9 \%)$, in which radical sequestering assay (RSA\%) was approximately $59 \%$ and $57 \%$ percent in eugenol and clove oil microemulsion, respectively. Results stated that the potential of eugenol-loaded microemulsion was enhanced compared to eugenol, which suggests the promising applications of eugenol microemulsion as a household disinfectant, preservation, and flavoring of food, personal hygiene products, disinfectant for wounds, prevention of hospitals transmitted infections, and as a mouth rinse for the avoidance of malodor caused by oral bacteria [69].

\subsection{Nanoemulsions}

Nanoemulsions consist of oil, water, and surfactants, which unlike microemulsions they are not formed spontaneously. Optimization of eugenol nanoemulsions was conducted for the assessment of its topical anti-inflammatory activity. Anti-inflammatory activity was examined in carrageenan-induced rats paw 
edema. The optimized formula was found to contain $2 \%$ eugenol (oil phase), $14 \%$ tween 20 (surfactant), and 14\% isopropyl alcohol (cosurfactant) in water. Comparative animal studies with the marketed piroxicam gel suggested that the nanoemulsions significantly enhanced antiinflammatory efficacy within $1.5 \mathrm{~h}$. Results showed that 1,2 , or $4 \%$ eugenol nanoemulsion formulations exhibited better anti-inflammatory effects relative to piroxicam commercial gel on carrageenan-induced edema in rats. Increasing the concentration of eugenol from $1 \%$ to $4 \%$ was not shown to induce greater inflammation inhibition. Besides, a comparison of nanoemulsion with and without piroxicam showed that piroxicam potentially lowered the anti-inflammatory activity of eugenol in the preparation. Moreover, the $2 \%$ eugenol nanoemulsion could be used as a substitute for topical NSAIDs [77].

In a similar study, another eugenol nanoemulsion was prepared and formulated in Carbopol $^{\circledR} 934$ gel for the prevention of periodontal inflammation. The nanoemulsion was formulated by the spontaneous emulsification method using oil phase (eugenol), surfactant tween-80, and co-surfactant polyethylene glycol (PEG). For the development of nanoemulsion, a 3-factor 3-level central composite design was utilized in which \% oil; \% water; and \% cosurfactant and surfactant mixture (Smix) were optimized as independent variables. The selected formulation showed a particle size of $79.92 \pm 6.33$ $\mathrm{nm}$, transmittance of $98.88 \pm 1.31 \%$, and a PDI of $0.229 \pm 0.019$, respectively. TEM and SEM showed a circular form of the nanoemulsion and drug content of $98.8 \pm 0.09 \% \mathrm{pH}(7.4 \pm 0.06)$, refractive index (1.63 \pm 0.038$)$, viscosity $(34.28 \pm 6$ $\mathrm{cp})$, and zeta potential (-19.16 \pm 0.11$)$. Eugenol nanoemulsion displayed significant antibacterial, analgesic, anesthetic, and anti-inflammatory efficacy, for the treatment of periodontal diseases due to its reduction of periodontal microbes and its modulatory effect on the inflammatory mechanism [78].

\subsection{Nanocapsules (NCs)}

Nanocapsules are polymeric-shelled nanocarriers, containing an oily core. Eugenolloaded polycaprolactone NCs were formulated by a method of solvent displacement. The in vitro release was observed to follow a biphasic mechanism. In the cell viability assay, the percentage of cell viability values were close to $100 \%$, showing that the NCs were not cytotoxic. The eugenol nanocapsules group demonstrated important variations in the continuity of the interdental papilla epithelium relative to the untreated, pure eugenol and placebo groups in the in vivo experiments. Using the ligature-induced periodontitis model in rats, the in vivo study revealed that the eugenol-loaded NCs could stop the resorption of septal bone in periodontitis. Therefore, eugenol-loaded polycaprolactone nanocapsules could be reported as a novel colloidal drug carrier system for enhancing the therapeutic efficacy of eugenol in periodontal infections [79].

In another study, the formulation of eugenol nanocapsules was attempted by interfacial precipitation of Eudragit $₫$ S100. Incorporation of eugenol in nanocapsules significantly reduced aural edema in rats which was induced by (12-OTetradecanoyl Phorbol-13-Acetate) TPA (i.e; $0.10 \pm 0.009 \mathrm{~mm}$ ) relative to the control group (NCB: $0.22 \pm 0.022 \mathrm{~mm}$ ). In comparison with the control group, the leukocyte infiltration and level of IL-6 were reduced, possibly due to irritancy blockage and improved skin permeation. It was also proven that polymeric nanocapsules did not induce contact hypersensitivity in rats developed by oxazolone. These findings indicate that eugenol nanoencapsulation is an interesting technique for the management of irritant contact dermatitis [80]. 


\subsection{Polymeric nanoparticles}

Chitosan is a positively charged polysaccharide employed as a wall/shell substance to enclose and cross-link with other materials bearing numerous negative charges. Improvement of eugenol thermal stability could be attained by encapsulating it into chitosantripolyphosphate (TPP) nanoparticles via an emulsion-ionic gelation crosslinking method. The encapsulated eugenol revealed approximately three-fold higher antioxidant effect and eight-fold greater remaining eugenol content than eugenol alone after going through a thermal process. Results proposed the promising antioxidant potential of eugenol-entrapped chitosan nanoparticles and their use in bioactive plastics for food packaging [81].

In another study for cerebral ischemia, eugenol-entrapped surface-modified nanoparticles were prepared to enhance its brain targeting through the intranasal route. Eugenolloaded-chitosan-coated- poly( $\varepsilon$-caprolactone) nanoparticles (CS-EUG-PCL-NPs) were developed and optimized. Pharmacokinetic studies showed that (CS-EUG-PCL-NPS) enhanced eugenol bioavailability in the brain of rats and therefore they may help in the alleviation of cerebral ischemia [82].

Eugenol loaded nanoparticles were formulated with Poly DL-lactide-co-glycolide (PLGA) for improving the antimicrobial activity. The nanoparticles were developed by the emulsion evaporation method in presence of surfactant (polyvinyl alcohol). The entrapment efficiency was nearly $98 \%$ and the release studies showed an initial rapid release "free eugenol" which later decreased with the release of eugenol entrapped inside the organic phase of the PLGA matrix. At the end of this study, eugenol was reported to be effective in the inhibition of Gram-negative bacterium (Salmonella spp.) and Gram-positive bacterium (Listeria spp.) at concentration ranges between 10-20 mg/mL [83].

\subsection{Solid lipid nanoparticles (SLN)}

SLNs are nanoparticulate systems formed from lipidic materials such as triglycerides, stabilized by a surfactant coat. SLN was used to enhance the antifungal efficacy of eugenol through the protection of eugenol from oxidative degradation. The effect of the combination of liquid lipid (caprylic triglyceride) and solid lipid (stearic acid) on SLN lipid matrix crystallinity was evaluated. Particle size findings revealed that SLN prepared using stearic acid single lipid matrix and SLN prepared using stearic acid and caprylic triglycerides dual lipid matrix was $332 \pm 14.2 \mathrm{~nm}$ and $87.8 \pm 3.8 \mathrm{~nm}$ in particle size respectively. The polydispersity index was found to be in the range of ( 0.27 to 0.4$)$, which showed a moderate distribution of size. The latter was found to have higher encapsulation efficiency $(98.52 \%)$ compared to the former $(91.80 \%)$ at the same concentration of lipids $(2 \% \mathrm{w} / \mathrm{v})$. The increase in solid lipid concentration from $2 \%$ $(\mathrm{w} / \mathrm{v})$ to $4 \%(\mathrm{w} / \mathrm{v})$ increased the efficiency of encapsulation and the size of SLN. Owing to the smaller size and involvement of liquid lipid, the latter formulation demonstrated a greater release of eugenol than the former, since it presented lesser barriers to drug diffusion from the matrix. In vivo studies were performed in immunosuppressed rats by using an oral candidiasis model, showing an enhancement of the therapeutic activity of eugenol. Therefore, eugenol loaded in SLN represents a significant alternative treatment in the case of resistant strains of fungi [84]. Results indicated that entrapment efficiency was dependent on lipid concentration. Consequently, this developed formulation is effective and provides an initial fast release for quick action with subsequent prolonged release of eugenol through changing the ratio of solid lipid (stearic acid) and liquid lipid (oleic acid) [85]. 


\subsection{Surfactant micelles}

Micelles are nanoparticles prepared by selfassembly of surfactant molecules in an aqueous environment. Eugenol loaded surfactant micelles were developed to enhance the suppressive effect on the growth of E. coli and L. monocytogenes. Surfynol 485W (water-soluble micellar nonionic

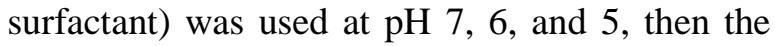
growth inhibition was determined at an incubation temperature of 10,22 , and $32{ }^{\circ} \mathrm{C}$. Antimicrobial activity was assessed using a micro broth dilution assay and the results revealed inhibition of both microorganisms. The presence of surfactants resulted in improved eugenol solubility in the watery phase and enhancement of the interactions with microorganisms. Overall, E. coli was more sensitive than $L$. monocytogenes to the formulation [86].

\subsection{Magnetic nanoparticles}

Magnetic nanoparticles (MNPs) coated with eugenol were prepared to increase the therapeutic activity of eugenol. First, magnetic nanoparticles of $\mathrm{Fe}_{3} \mathrm{O}_{4}$ were developed through chemical coprecipitation reaction and their surface was coated with silica, then, the surface of the magnetic nanoparticles was covered by eugenol. Characterization of the prepared MNPs proved the effective coating of MNPs with silica and eugenol. The prepared system showed enhanced cytotoxic efficacy than eugenol, especially against human ovarian carcinoma. Efficient coating of magnetic nanoparticles (MNPs) with silica and eugenol and the circular form of nanoparticles with a mean diameter of fifteen nanometers have been recorded. The analysis of the in vitro cytotoxicity of eugenol-MNPs and eugenol versus three human cancer cell lines (human lung carcinoma, human glioblastoma astrocytoma, and human ovarian carcinoma) revealed that the cytotoxicity of nanoparticles was slightly higher in human ovarian carcinoma (i.e; $\mathrm{IC}_{50} 25.34 \mu \mathrm{g} / \mathrm{mL}$ and $100.57 \mu \mathrm{g} / \mathrm{mL}$ ) for eugenol-MNPs and native eugenol, respectively. It is worth mentioning that plain MNPs did not induce any cytotoxicity at the utilized concentrations. Antimicrobial activity conducted on Acinetobacter baumannii, Klebsiella pneumonia, Staphylococcus aureus, and E. coli, showed increased inhibition zone than free eugenol [87].

\subsection{Liposomes}

Liposomes are vesicular nanoparticles prepared by self-assembly of phospholipids in aqueous media. Eugenol-entrapped liposomes were reported to enhance eugenol stability. The vesicles were formulated with different soybean phospholipids, cholesterol, and various concentrations of clove oil and eugenol. The developed liposomes showed high entrapment efficiency values for eugenol and reduced its degradation by UV exposure. It was found that the entrapment efficiency of eugenol-entrapped liposomes ranged from (70-90\%) of the total eugenol added at the different concentrations of prepared liposomal components. Liposomes were also stable after sixty days of storage at $4{ }^{\circ} \mathrm{C}$. The DPPH antioxidant activity of free eugenol was maintained over the study [88].

\subsection{Ethosomes}

Ethosomes are analogous to liposomes, but they contain ethanol as an integral component of the phospholipid bilayer. The antibacterial efficiency of eugenol loaded ethosomes against fruit anthracnose (i.e. fungal disease that affects many plants) was investigated. With a size of $44.21 \mathrm{~nm}$ and entrapment efficiency of $82 \%$, the optimized formula (i.e. $2 \%$ lecithin, $0.5 \%$ eugenol, and $30 \%$ ethanol) displayed an antibacterial efficacy (more than 93\%) against fruit pathogens that was greater than that of free eugenol after six days and exhibited complete inhibition of the occurrence of anthracnose in 
post-harvest plants [89].

Table 2. Different novel eugenol delivery systems

\begin{tabular}{|c|c|c|c|c|}
\hline Nanocarriers & Method of preparation & Results & Therapeutic use(s) & Ref. \\
\hline Microemulsions & Oil titration method & $\begin{array}{l}\text { - Microemulsions exhibited larger } \\
\text { inhibition zone diameters than } \\
\text { corresponding crude counterparts } \\
\text { - The radical sequestering assay } \\
\text { (RSA\%) was approximately fifty- } \\
\text { nine and fifty-seven percent in } \\
\text { eugenol and clove oil } \\
\text { microemulsion, respectively. }\end{array}$ & $\begin{array}{l}\text { - Household disinfectant } \\
\text { - Preservation and } \\
\text { flavoring of food } \\
\text { - Personal } \\
\text { products } \\
\text { - Disinfectant } \\
\text { wounds, prevention of } \\
\text { hospitals transmitted } \\
\text { infections } \\
\text { - Mouth rinse for the } \\
\text { avoidance of malodor } \\
\text { caused by oral bacteria }\end{array}$ & [69] \\
\hline Nanoemulsions & $\begin{array}{l}\text { Spontaneous emulsification } \\
\text { method }\end{array}$ & $\begin{array}{l}\text { - Particle size: } 79.92 \pm 6.33 \mathrm{~nm} \text {, } \\
\text { - Transmittance } \%: 98.88 \pm 1.31 \% \\
\text { - Polydispersity index: } 0.229 \pm \\
0.019 \\
\text { - Drug content of } 98.8 \pm 0.09 \% \\
\text { - Zeta potential }(-19.16 \pm 0.11 \mathrm{mV})\end{array}$ & $\begin{array}{l}\text { - Antibacterial } \\
\text { - Analgesic } \\
\text { - Anesthetic } \\
\text { - The anti-inflammatory } \\
\text { effect in periodontal disease }\end{array}$ & [78] \\
\hline \multirow[t]{2}{*}{ Nanocapsules } & $\begin{array}{l}\text { Solvent displacement } \\
\text { method }\end{array}$ & $\begin{array}{l}\text { - Nanocapsules exhibited a biphasic } \\
\text { release mechanism } \\
\text { - Nanocapsules were proven not } \\
\text { cytotoxic. } \\
\text { - Nanocapsules could stop } \\
\text { resorption of septal bone in } \\
\text { periodontitis }\end{array}$ & $\begin{array}{l}\text { - The anti-inflammatory } \\
\text { effect in periodontal } \\
\text { infections }\end{array}$ & [79] \\
\hline & Interfacial precipitation & $\begin{array}{l}\text { - Reduction in aural edema in rats } \\
\text { induced by (12-O-Tetradecanoyl } \\
\text { Phorbol-13-Acetate) TPA relative to } \\
\text { the control group } \\
\text { - In comparison with the control } \\
\text { group, the leukocyte infiltration and } \\
\text { level of IL-6 were reduced } \\
\text { - Polymeric nanocapsules did not } \\
\text { induce contact hypersensitivity in } \\
\text { rats }\end{array}$ & $\begin{array}{l}\text { - Management of irritant } \\
\text { contact dermatitis }\end{array}$ & [80] \\
\hline \multirow[t]{2}{*}{$\begin{array}{l}\text { Polymeric } \\
\text { nanoparticles }\end{array}$} & $\begin{array}{l}\text { Emulsion-ionic gelation } \\
\text { crosslinking method }\end{array}$ & $\begin{array}{l}\text { - The encapsulated eugenol } \\
\text { revealed approximately three-fold } \\
\text { higher antioxidant effect and eight- } \\
\text { fold greater remaining eugenol } \\
\text { content than eugenol alone }\end{array}$ & $\begin{array}{l}\text { - Antioxidant } \\
\text { - Used in bioactive } \\
\text { plastics for food packaging }\end{array}$ & [81] \\
\hline & $\begin{array}{l}\text { Double emulsification- } \\
\text { solvent evaporation } \\
\text { technique }\end{array}$ & $\begin{array}{l}\text { - Mean particles size }(224.5 \pm 5.31) \\
\mathrm{nm} \\
\text { - Polydispersity index }(0.216 \pm \\
0.020)\end{array}$ & $\begin{array}{l}\text { - Cerebral ischemia } \\
\text { - Enhance brain } \\
\text { targeting through the } \\
\text { intranasal route }\end{array}$ & [82] \\
\hline
\end{tabular}




\begin{tabular}{|c|c|c|c|c|}
\hline & & $\begin{array}{l}\text { - } \text { Entrapment efficiency }(68.13 \pm \\
5.03) \% \\
\text { - High mucoadhesive potential } \\
\text { - Pharmacokinetic studies in } \\
\text { Wistar rat brain and plasma } \\
\text { exhibited a high AUC }{ }_{0-24} \text { with } \\
\text { an amplified } \mathrm{C}_{\max } \text { compared to } \\
\text { IV treated group }\end{array}$ & & \\
\hline & $\begin{array}{l}\text { Emulsion evaporation } \\
\text { method }\end{array}$ & $\begin{array}{l}\bullet \mathrm{EE} \%: 98 \% \\
\text { - In vitro release showed sustained } \\
\text { release from PLGA matrix }\end{array}$ & $\begin{array}{lr}\text { - Inhibition of Gram- } & \text { of } \\
\text { negative } & \text { bacterium } \\
\text { (Salmonella spp.) and } & \text { sp.) acterium } \\
\text { Gram-positive } & \text { bam. } \\
\text { (Listeria spp.) } & \end{array}$ & [83] \\
\hline \multirow[t]{7}{*}{ SLN } & $\begin{array}{l}\text { Hot homogenization } \\
\text { ultrasonication method }\end{array}$ & $\begin{array}{l}\text { - Particle size ranged from } 87.8 \pm 3.8 \\
\mathrm{~nm} \text { to } 332 \pm 14.2 \mathrm{~nm} \\
\text { - The polydispersity ranged from } \\
0.27-0.4\end{array}$ & - Antifungal activity & [84] \\
\hline & & $\begin{array}{l}\text { - Encapsulation efficiency ranging } \\
\text { from } 91.8 \% \text { to } 98.52 \%\end{array}$ & & \\
\hline & $\begin{array}{l}\text { Hot homogenization } \\
\text { method }\end{array}$ & $\begin{array}{l}\text { - Particle size was found to be } \\
\text { approximately }(206 \pm 2.5 \mathrm{~nm})\end{array}$ & $\begin{array}{l}\text { - The anti-inflammatory } \\
\text { effect in periodontitis }\end{array}$ & [85] \\
\hline & & • $\quad$ PDI : $0.62 \pm 0.002$ & & \\
\hline & & $\begin{array}{l}\text { - Encapsulation efficiency ranged } \\
\text { from } 71-97 \%\end{array}$ & & \\
\hline & & $\begin{array}{l}\text { - In vitro release from the gel } \\
\text { showed its sustained release } \\
\text { potential as compared to plain } \\
\text { drug-loaded gel }\end{array}$ & & \\
\hline & & $\begin{array}{l}\text { - Stability study revealed its } \\
\text { stability over } 6 \text { months }\end{array}$ & & \\
\hline $\begin{array}{l}\text { Surfactant } \\
\text { micelles }\end{array}$ & $\begin{array}{l}\text { Solution straining of } \\
\text { Surfynol } 485 \mathrm{~W} \text { (aqueous } \\
\text { micellar nonionic } \\
\text { surfactant) }\end{array}$ & $\begin{array}{l}\text { Inhibition of both microorganisms } \\
(E . \quad \text { coli and Listeria } \\
\text { monocytogenes) but E. coli was } \\
\text { more sensitive than L. } \\
\text { monocytogenes to the formulation }\end{array}$ & $\begin{array}{l}\text { - Suppressive effect on } \\
\text { the growth of E. coli and } \\
\text { Listeria monocytogenes }\end{array}$ & [86] \\
\hline \multirow[t]{2}{*}{$\begin{array}{l}\text { Magnetic } \\
\text { nanoparticles }\end{array}$} & $\begin{array}{l}\text { Chemical co-precipitation } \\
\text { reaction }\end{array}$ & $\begin{array}{l}\text { - Circular nanoparticles with a } \\
\text { mean diameter of } 15 \mathrm{~nm} \\
\text { - Efficient coating of magnetic } \\
\text { nanoparticles (MNPs) with silica } \\
\text { and eugenol }\end{array}$ & $\begin{array}{l}\text { - Antimicrobial activity on } \\
\text { Acinetobacter baumannii, } \\
\text { Klebsiella pneumonia, } \\
\text { Staphylococcus aureus, and } \\
\text { E. coli }\end{array}$ & [87] \\
\hline & & $\begin{array}{l}\text { - Antimicrobial activity conducted } \\
\text { showed } 1.5 \text { times greater inhibition } \\
\text { zone of developed nanoparticles } \\
\text { than free eugenol on all } \\
\text { microorganisms studied }\end{array}$ & & \\
\hline
\end{tabular}




\begin{tabular}{|c|c|c|c|c|}
\hline & & $\begin{array}{l}\text { - Good cytotoxic efficacy against } \\
\text { human ovarian carcinoma for } \\
\text { eugenol-MNPs and native eugenol } \\
\text { - Plain MNPs did not induce any } \\
\text { cytotoxicity at used concentrations }\end{array}$ & & \\
\hline Liposomes & Ethanol injection method & $\begin{array}{l}\text { Particle size ranged from ( } 275 \\
\text { to } 330 \mathrm{~nm}) \\
\text { PDI: } 0.14 \pm 0.08 \\
\text { - } \quad \text { Encapsulation } \\
\text { ranged from }(70 \text { to } 90 \% \text { ) } \\
\text { - Eugenol loading rate ranged } \\
\text { from ( } 23 \text { to } 36 \%) \text { from the } \\
\text { total eugenol added. } \\
\text { - Liposomes were stable after } \\
\text { sixty days of storage at } 4^{0} \mathrm{C} \\
\text { The DPPH antioxidant activity } \\
\text { (RSA \%) was } 80 \%\end{array}$ & Antioxidant & [88] \\
\hline Ethosomes & Ethanol injection method & $\begin{array}{l}\text { - Particle size: } 44.21 \mathrm{~nm} \\
\text { - } \quad \text { PDI: } 0.19 \pm 0.05 \\
\text { - The entrapment efficiency of } \\
82 \% \\
\text { - Antibacterial efficacy (more } \\
\text { than 93\%) against fruit } \\
\text { pathogens greater than free } \\
\text { eugenol after six days, with } \\
\text { complete inhibition of the } \\
\text { occurrence of fruit anthracnose. }\end{array}$ & $\begin{array}{l}\text { - Antibacterial efficiency } \\
\text { against fruit anthracnose } \\
\text { (i.e. fungal disease that } \\
\text { affects many plants) } \\
\text { - Antifungal activity } \\
\text { against fruit pathogens }\end{array}$ & [89] \\
\hline
\end{tabular}

\section{Conclusion}

This study describes the efficacy of eugenol as a herbal substance with many curative indications. It has tremendous valuable pharmacological activities like antioxidant, antimicrobial, and anti-inflammatory effects. Incorporation of eugenol in various nano-based systems, (such as microemulsions, liposomes, ethosomes, nanocapsules, and surfactant micelles), has been reported as a promising choice to overcome some physicochemical incompatibilities of eugenol as its volatility, light sensitivity, and its irritant effect.

\section{Declarations}

\section{Ethics approval and consent to participate}

Not applicable

\section{Consent to publish}

Not applicable

\section{Availability of data and materials}

All data generated or analyzed during this study are included in this published article in the main manuscript.

\section{Competing interests}

No competing interests were declared by the authors.

\section{Funding statement}

No funding source was received

\section{REFERENCES}

1. U. K. Sharma, A. K. Sharma, and A. K. Pandey, "Medicinal attributes of major phenylpropanoids present in cinnamon," BMC Complement. Altern. Med., vol. 16, no. 1, pp. 1-11, 2016, doi: 10.1186/s12906-016-1147-4. 
2. C. K. Park et al., "Molecular mechanism for local anesthetic action of eugenol in the rat trigeminal system," Pain, vol. 144, no. 1-2, pp. 84-94, Jul. 2009, doi: 10.1016/j.pain.2009.03.016.

3. M. M. Said and M. M. A. Rabo, "Neuroprotective effects of eugenol against aluminum-induced toxicity in the rat brain," Arh. Hig. Rada Toksikol., vol. 68, no. 1, pp. 2737, 2017, doi: 10.1515/aiht-2017-68-2878.

4. T. Suanarunsawat, W. D. Na Ayutthaya, T. Songsak, and J. Rattanamahaphoom, "Antilipidemic actions of essential oil extracted from Ocimum sanctum L. leaves in rats fed with high cholesterol diet," J. Appl. Biomed., vol. 7, no. 1, pp. 45-53, 2009, doi: 10.32725/jab.2009.004.

5. G. Anuj, S. Sanjay, C. Author, and B. Hindu, "Newsletter Anuj and Sanjay Pharmacologyonline 2: $\quad 108-120 \quad$ (2010) Newsletter Anuj and Sanjay," vol. 120, pp. 108120, 2010.

6. S. Saran, S. Menon, S. Shailajan, and P. Pokharna, "Validated RP-HPLC method to estimate eugenol from commercial formulations like Caturjata Churna, Lavangadi Vati, Jatiphaladi Churna, Sitopaladi Churna, and clove oil," J. Pharm. Res., vol. 6, no. 1, pp. 5360, 2013, doi: 10.1016/j.jopr.2012.11.013.

7. B. Al-Trad, H. Alkhateeb, W. Alsmadi, and M. Al-Zoubi, "Eugenol ameliorates insulin resistance, oxidative stress and inflammation in high fat-diet/streptozotocin-induced diabetic rat," Life Sci., vol. 216, pp. 183-188, 2019, doi: 10.1016/j.lfs.2018.11.034.

8. D. P. Bezerra, G. C. G. Militão, M. C. De Morais, and D. P. De Sousa, "The dual antioxidant/prooxidant effect of eugenol and its action in cancer development and treatment," Nutrients, vol. 9, no. 12, pp. 1-15, 2017, doi: 10.3390/nu9121367.

9. G. P. Kamatou, I. Vermaak, and A. M. Viljoen, "Eugenol - From the remote Maluku Islands to the international market place: A review of a remarkable and versatile molecule," Molecules, vol. 17, no. 6, pp. 6953-6981, 2012, doi: 10.3390/molecules17066953.
10. W. Guan, S. Li, R. Yan, S. Tang, and C. Quan, "Comparison of essential oils of clove buds extracted with supercritical carbon dioxide and other three traditional extraction methods," Food Chem., vol. 101, no. 4, pp. 1558-1564, 2007, doi: 10.1016/j.foodchem.2006.04.009.

11. N. Jeyaratnam, A. H. Nour, R. Kanthasamy, A. H. Nour, A. R. Yuvaraj, and J. O. Akindoyo, "Essential oil from Cinnamomum cassia bark through hydro distillation and advanced microwave-assisted hydrodistillation," Ind. Crops Prod., vol. 92, pp. 57-66, 2016, doi: 10.1016/j.indcrop.2016.07.049.

12. Y. L. - A.-S. F.-T. F. Chemat, Essential Oils as Reagents in Green Chemistry, vol. 245, no. 8. 2015.

13. D. Chatterjee and P. Bhattacharjee, "Supercritical Carbon Dioxide Extraction of Eugenol from Clove Buds: Process Optimization and Packed Bed Characterization," Food Bioprocess Technol., vol. 6, no. 10, pp. 25872599, 2013, doi: 10.1007/s11947-012-0979-2.

14. F. Chemat, Zill-E-Huma, and M. K. Khan, "Applications of ultrasound in food technology: Processing, preservation, and extraction," Ultrason. Sonochem., vol. 18, no. 4, pp. 813835, 2011, doi: 10.1016/j.ultsonch.2010.11.023.

15. M. A. Kurniawan, S. Matsjeh, and S. Triono, "Conversion of eugenol to methyleugenol: Computational study and experimental," AIP Conf. Proc., vol. 1823, no. March, pp. 1-9, 2017, doi: 10.1063/1.4978182.

16. A. A. Khalil, U. U. Rahman, M. R. Khan, A. Sahar, T. Mehmood, and M. Khan, "Essential oil eugenol: Sources, extraction techniques and nutraceutical perspectives," RSC Advances, vol. 7, no. 52. 2017, doi: 10.1039/c7ra04803c.

17. D. Y. Kim, K. J. Won, D. Il Hwang, S. M. Park, B. Kim, and H. M. Lee, "Chemical Composition, Antioxidant and Anti-melanogenic Activities of Essential Oils from Chrysanthemum boreale Makino at Different Harvesting Stages," Chem. Biodivers., vol. 15, no. 2, Feb. 2018, doi: 10.1002/cbdv.201700506.

18. J. N. Barboza, C. da Silva Maia Bezerra Filho, 
R. O. Silva, J. V. R. Medeiros, and D. P. de Sousa, "An overview on the anti-inflammatory potential and antioxidant profile of eugenol," Oxid. Med. Cell. Longev., vol. 2018, 2018, doi: 10.1155/2018/3957262.

19. A. Hussain, K. Brahmbhatt, A. Priyani, M. Ahmed, T. A. Rizvi, and C. Sharma, "Eugenol enhances the chemotherapeutic potential of gemcitabine and induces anticarcinogenic and anti-inflammatory activity in human cervical cancer cells," Cancer Biother. Radiopharm., vol. 26, no. 5, pp. 519-527, Oct. 2011, doi: 10.1089/cbr.2010.0925.

20. M. Fathy, M. A. Fawzy, H. Hintzsche, T. Nikaido, T. Dandekar, and E. M. Othman, "Eugenol exerts apoptotic effect and modulates the sensitivity of HeLa cells to cisplatin and radiation," Molecules, vol. 24, no. 21, 2019, doi: 10.3390/molecules24213979.

21. P. Manikandan, R. S. Murugan, R. V. Priyadarsini, G. Vinothini, and S. Nagini, "Eugenol induces apoptosis and inhibits invasion and angiogenesis in a rat model of gastric carcinogenesis induced by MNNG," Life Sci., vol. 86, no. 25-26, pp. 936-941, 2010, doi: 10.1016/j.lfs.2010.04.010.

22. H. Nam and M. M. Kim, "Eugenol with antioxidant activity inhibit MMP-9 related to metastasis in human fibrosarcoma cells," Food Chem. Toxicol., vol. 55, pp. 106-112, May 2013, doi: 10.1016/j.fct.2012.12.050.

23. G. Rita, M. Ganapathy, W. L. Alworth, D. C. Chan, and A. P. Kumar, "Combination of 2methoxyestradiol (2-ME2) and eugenol for apoptosis induction synergistically in androgenindependent prostate cancer cells," J. Steroid Biochem. Mol. Biol., vol. 113, no. 1-2, pp. 2535, Jan. 2009, doi: 10.1016/j.jsbmb.2008.11.002.

24. X. Kong, X. Liu, J. Li, and Y. Yang, “Advances in pharmacological research of eugenol," Curr. Opin. Complement. Altern. Med., vol. 1, no. 1, pp. 8-11, 2014, doi: 10.7178/cocam.7.

25. S. S. Islam, I. Al-Sharif, A. Sultan, A. AlMazrou, A. Remmal, and A. Aboussekhra,
"Eugenol potentiates cisplatin anti-cancer activity through inhibition of ALDH-positive breast cancer stem cells and the NF- $\kappa B$ signaling pathway," Mol. Carcinog., vol. 57, no. 3, pp. 333-346, 2018, doi: 10.1002/mc.22758.

26. L. Fangjun and Y. Zhijia, "Tumor suppressive roles of eugenol in human lung cancer cells," Thorac. Cancer, vol. 9, no. 1, pp. 25-29, 2018, doi: 10.1111/1759-7714.12508.

27. F. Chami, N. Chami, S. Bennis, J. Trouillas, and A. Remmal, "Evaluation of carvacrol and eugenol as prophylaxis and treatment of vaginal candidiasis in an immunosuppressed rat model," J. Antimicrob. Chemother., vol. 54, no. 5, pp. 909-914, 2004, doi: 10.1093/jac/dkh436.

28. E. Schmidt et al., "Antifungal Activity of Eugenol and Various Eugenol-Containing Essential Oils against 38 Clinical Isolates of Candida albicans," J. Essent. Oil-Bearing Plants, vol. 10, no. 5, pp. 421-429, 2007, doi: 10.1080/0972060X.2007.10643575.

29. F. Nazzaro, F. Fratianni, R. Coppola, and V. De Feo, "Essential oils and antifungal activity," Pharmaceuticals, vol. 10, no. 4, pp. 1-20, 2017, doi: 10.3390/ph10040086.

30. E. Pinto, L. Vale-Silva, C. Cavaleiro, and L. Salgueiro, "Antifungal activity of the clove essential oil from Syzygium aromaticum on Candida, Aspergillus and dermatophyte species," J. Med. Microbiol., vol. 58, no. 11, pp. 1454-1462, 2009, doi: 10.1099/jmm.0.0105380.

31. M. A. E.-B. Rehab and S. H. Zeinab, "Eugenol and linalool: Comparison of their antibacterial and antifungal activities," African J. Microbiol. Res., vol. 10, no. 44, pp. 1860-1872, 2016, doi: 10.5897/ajmr2016.8283.

32. K. A. Abd-Elsalam and A. R. Khokhlov, "Eugenol oil nanoemulsion: antifungal activity against Fusarium oxysporum f. sp. vasinfectum and phytotoxicity on cottonseeds," Appl. Nanosci., vol. 5, no. 2, pp. 255-265, 2015, doi: 10.1007/s13204-014-0398-y.

33. A. Basak, R. Chakraborty, and S. M. Mandal, Recent trends in antifungal agents and antifungal 
therapy. 2016.

34. S. M. Leal Pinto, L. V. Herrera Sandoval, and L. Y. Vargas, "In vitro susceptibility of Microsporum spp. and mammalian cells to Eugenia caryophyllus essential oil, eugenol and semisynthetic derivatives," Mycoses, vol. 62, no. 1, pp. 41-50, 2019, doi: 10.1111/myc.12844.

35. M. K. Mak KK, Kamal MB, “A Comprehensive Review on Eugenol's Antimicrobial Properties and Industry Applications: A Transformation from Ethnomedicine to Industry," Pharmacogn. Rev., vol. 13, no. 25, pp. 1-9, 2019, doi: 10.4103/phrev.phrev.

36. S. Jaidka, R. Somani, D. J. Singh, T. Sheikh, N. Chaudhary, and A. Basheer, "Herbal combat against E. faecalis - An in vitro study," J. Oral Biol. Craniofacial Res., vol. 7, no. 3, pp. 178181, 2017, doi: 10.1016/j.jobcr.2017.08.001.

37. R. Firyanto, E. P. Fatarina, and N. Azizah, "Effectiveness of Eugenol as An Antibacterial Toward Staphylococcus epidermidis," J. Phys. Conf. Ser., vol. 1295, no. 1, 2019, doi: 10.1088/1742-6596/1295/1/012034.

38. M. K. Yadav, S. W. Chae, G. J. Im, J. W. Chung, and J. J. Song, "Eugenol: A phytocompound effective against methicillin-resistant and methicillin-sensitive Staphylococcus aureus clinical strain biofilms," PLoS One, vol. 10, no. 3, pp. 1-21, 2015, doi: 10.1371/journal.pone.0119564.

39. Q. Liu, X. Meng, Y. Li, C. N. Zhao, G. Y. Tang, and $\mathrm{H}$. Bin Li, "Antibacterial and antifungal activities of spices," Int. J. Mol. Sci., vol. 18, no. 6, pp. 1-62, 2017, doi: 10.3390/ijms 18061283.

40. K. P. Devi, S. A. Nisha, R. Sakthivel, and S. K. Pandian, "Eugenol (an essential oil of clove) acts as an antibacterial agent against Salmonella typhi by disrupting the cellular membrane," J. Ethnopharmacol., vol. 130, pp. 107-115, 2010, doi: 10.1016/j.jep.2010.04.025.

41. Y. Zhang, Y. Wang, X. Zhu, Y. Lu, P. Cao, and S. Wei, "Antibacterial and antibiofilm activities of eugenol from the essential oil of Syzygium aromaticum (L.) Merr. \& L. M. Perry (clove) leaf against periodontal pathogen
Porphyromonas gingivalis," Microb. Pathog., vol. 113, pp. 396-402, 2017, doi: 10.1016/j.micpath.2017.10.054.

42. A. L. De Almeida et al., "Eugenol and derivatives activity against Mycobacterium tuberculosis, nontuberculous mycobacteria and other bacteria," Future Microbiol., vol. 14, no. 4, pp. 331-344, 2019, doi: 10.2217/fmb-20180333.

43. T. H. Tsai et al., "Clove extract and eugenol suppress inflammatory responses elicited by Propionibacterium acnes in vitro and in vivo," Food Agric. Immunol., vol. 28, no. 5, pp. 916931, 2017, doi: 10.1080/09540105.2017.1320357.

44. $\mathrm{Y}$. $\mathrm{Wu}$ et al., "Antibacterial activity and membrane-disruptive mechanism of 3-p-transcoumaroyl-2-hydroxyquinic acid, a novel phenolic compound from pine needles of Cedrus deodara, against Staphylococcus aureus," Molecules, vol. 21, no. 8, 2016, doi: 10.3390/molecules21081084.

45. F. Nazzaro, F. Fratianni, L. De Martino, R. Coppola, and V. De Feo, "Effect of essential oils on pathogenic bacteria," Pharmaceuticals, vol. 6, no. 12, pp. 1451-1474, 2013, doi: 10.3390/ph6121451.

46. M. R. Charan Raja, V. Srinivasan, S. Selvaraj, and S. K. Mahapatra, "Versatile and Synergistic Potential of Eugenol: A Review," Pharm. Anal. Acta, vol. 6, no. 6, pp. 1-6, 2015, doi: 10.4172/21532435.1000367.

47. Y. G. Kim, J. H. Lee, G. Gwon, S. Il Kim, J. G. Park, and J. Lee, "Essential Oils and Eugenol Inhibit Biofilm Formation and the Virulence of Escherichia coli O157:H7," Sci. Rep., vol. 6, pp. 1-11, 2016, doi: 10.1038/srep36377.

48. M. Islamuddin, G. Chouhan, M. Y. Want, H. A. Ozbak, H. A. Hemeg, and F. Afrin, "Immunotherapeutic Potential of Eugenol Emulsion in Experimental Visceral Leishmaniasis," PLoS Negl. Trop. Dis., pp. 123, 2016, doi: 10.1371/journal.pntd.0005011.

49. L. M. Katiki, A. M. E. Barbieri, R. C. Araujo, C. J. Veríssimo, H. Louvandini, and J. F. S. 
Ferreira, "Synergistic interaction of ten essential oils against Haemonchus contortus in vitro," Vet. Parasitol., vol. 243, pp. 47-51, 2017, doi: 10.1016/j.vetpar.2017.06.008.

50. A. M. El-kady, A. A. Ahmad, T. M. Hassan, H. E. M. El-Deek, S. S. Fouad, and S. S. Althagfan, "Eugenol, a potential schistosomicidal agent with anti-inflammatory and antifibrotic effects against Schistosoma mansoni, induced liver pathology," Infect. Drug Resist., vol. 12, pp. 709-719, 2019, doi: 10.2147/IDR.S196544.

51. D. A. P. Mancini, R. P. Torres, J. R. Pinto, and J. Mancini-Filho, "Inhibition of DNA Virus: Herpes-1 (HSV-1) in cellular culture replication, through an antioxidant treatment extracted from rosemary spice," Brazilian J. Pharm. Sci., vol. 45, no. 1, pp. 127-133, 2009, doi: 10.1590/S1984-82502009000100016.

52. G. Anuj and S. Sanjay, "Eugenol: a potential phytochemical with multifaceted therapeutic activities," Pharmacol. Newsl. Anuj Sanjay, no. 2, pp. 108-120, 2010.

53. T. Lane, M. Anantpadma, J. S. Freundlich, R. A. Davey, P. B. Madrid, and S. Ekins, "The Natural Product Eugenol Is an Inhibitor of the Ebola Virus In Vitro," Pharm. Res., vol. 36, no. 7, pp. 2-7, 2019, doi: 10.1007/s11095-0192629-0.

54. Z. Cui et al., "Eugenol inhibits non-small cell lung cancer by repressing expression of NF- $\mathrm{KB}$ regulated TRIM59," Phyther. Res., vol. 33, no. 5, pp. 1562-1569, 2019, doi: 10.1002/ptr.6352.

55. H. Gholipourkanani, I. Gholinasab-Omran, P. Ebrahimi, and H. Jafaryan, "Anesthetic effect of clove Oil loaded on lecithin based nanoemulsions in goldfish, Carassius auratus," J. Fish. Aquat. Sci., vol. 10, no. 6, pp. 553-561, 2015, doi: 10.3923/jfas.2015.553.561.

56. S. Mohammadi Nejad, H. Özgüneş, and N. Başaran, "Pharmacological and Toxicological Properties of Eugenol," Turkish J. Pharm. Sci., vol. 14, no. 2, pp. 201-206, 2017, doi: 10.4274/tjps.62207.

57. C. Pan and Z. Dong, "Antiasthmatic Effects of Eugenol in a Mouse Model of Allergic Asthma by Regulation of Vitamin D3 Upregulated Protein 1/NF-kB Pathway," Inflammation, vol. 38, no. 4, pp. 1385-1393, 2015, doi: 10.1007/s10753-015-0110-8.

58. S. A. Sheweita, L. S. El-Hosseiny, and M. A. Nashashibi, "Protective effects of essential oils as natural Antioxidants against hepatotoxicity induced by cyclophosphamide in mice," PLoS One, vol. 11, no. 11, pp. 1-17, 2016, doi: 10.1371/journal.pone.0165667.

59. D. M. Abd El Motteleb, S. A. Selim, and A. M. Mohamed, "Differential effects of eugenol against hepatic inflammation and overall damage induced by ischemia/reperfusion injury," J. Immunotoxicol., vol. 11, no. 3, pp. 238-245, 2014, doi: 10.3109/1547691X.2013.832444.

60. D. S. Patil, M. B. Jograna, and S. V Kotwal, "Profile of eugenia caryophyllum one of the most useful traditional herbal drug in india," world J. Pharm. Res., vol. 9, no. 5, pp. 15891606, 2020, doi: 10.20959/wjpr20205-17409.

61. M. H. Lee et al., "Eugenol inhibits calcium currents in dental afferent neurons," J. Dent. Res., vol. 84, no. 9, pp. 848-851, 2005, doi: $10.1177 / 154405910508400913$.

62. R. A. Antora and R. M. Salleh, "Antihyperglycemic effect of Ocimum plants: A short review," Asian Pac. J. Trop. Biomed., vol. 7, no. 8, pp. 755-759, 2017, doi: 10.1016/j.apjtb.2017.07.010.

63. P. Singh et al., "Potential dual role of eugenol in inhibiting advanced glycation end products in diabetes: Proteomic and mechanistic insights," Sci. Rep., vol. 6, no. January, pp. 1-13, 2016, doi: 10.1038/srep18798.

64. A. Alqareer, A. Alyahya, and L. Andersson, "The effect of clove and benzocaine versus placebo as topical anesthetics," J. Dent., vol. 34, no. 10, pp. 747-750, Nov. 2006, doi: 10.1016/j.jdent.2006.01.009.

65. K. Pramod, S. H. Ansari, and J. Ali, "Eugenol: A natural compound with versatile pharmacological actions," Nat. Prod. Commun., vol. 5, no. 12, pp. 1999-2006, 2010, doi: 


\section{$10.1177 / 1934578 \times 1000501236$}

66. D. C. A. Moreira-Lobo et al., "Eugenol modifies the excitability of rat sciatic nerve and superior cervical ganglion neurons," Neurosci. Lett., vol. 472, no. 3, pp. 220-224, Mar. 2010, doi: 10.1016/j.neulet.2010.02.009.

67. K. Dubey, B. G. Anand, D. S. Shekhawat, and K. Kar, "Eugenol prevents the amyloid formation of proteins and inhibits amyloidinduced hemolysis," Sci. Rep., vol. 7, Feb. 2017, doi: 10.1038/srep40744.

68. C. F. Moreira Vasconcelos et al., "Eugenol and its association with levodopa in 6-hydroxydopamine-induced hemiparkinsonian rats: Behavioural and neurochemical alterations," Basic Clin. Pharmacol. Toxicol., vol. 127 , no. 4 , pp. 287-302, Oct. 2020, doi: $10.1111 / \mathrm{bcpt} .13425$.

69. S. F. Hamed, Z. Sadek, and A. Edris, "Antioxidant and antimicrobial activities of clove bud essential oil and eugenol nanoparticles in the alcohol-free microemulsion," J. Oleo Sci., vol. 61, no. 11, pp. 641-648, 2012, doi: 10.5650/jos.61.641.

70. S. N. Prasad and Muralidhara, "Evidence of acrylamide induced oxidative stress and neurotoxicity in Drosophila melanogaster - Its amelioration with spice active enrichment: Relevance to neuropathy," Neurotoxicology, vol. 33, no. 5, pp. 1254-1264, Oct. 2012, doi: 10.1016/j.neuro.2012.07.006.

71. D. Garabadu et al., "Eugenol as an anti-stress agent: Modulation of the hypothalamicpituitary-adrenal axis and brain monoaminergic systems in a rat model of stress," Stress, vol. 14, no. 2, pp. 145-155, Mar. 2011, doi: 10.3109/10253890.2010.521602.

72. S. Kar Mahapatra, S. P. Chakraborty, S. Majumdar, B. G. Bag, and S. Roy, "Eugenol protects nicotine-induced superoxide mediated oxidative damage in murine peritoneal macrophages in vitro," Eur. J. Pharmacol., vol. 623, no. 1-3, pp. 132-140, Nov. 2009, doi: 10.1016/j.ejphar.2009.09.019.

73. K. Venkadeswaran et al.,
"Antihypercholesterolemic and antioxidative potential of an extract of the plant, Piper betel, and its active constituent, eugenol, in triton WR1339-Induced hypercholesterolemia in experimental rats," Evidence-based Complement. Altern. Med., vol. 2014, pp. 1-11, 2014, doi: 10.1155/2014/478973.

74. A. Munisa and W. Manalu, "The Effect of Clove Leaf Methanol Extract on the Profiles of Superoxide Dismutase and Malondialdehyde in the Liver of Rabbits under Hypercholesterolemia Condition," Transl. Biomed., vol. 6, no. 2, pp. 1-5, 2015, doi: 10.21767/2172-0479.100012.

75. I. Agustinisari, K. Mulia, and M. Nasikin, "The effect of eugenol and chitosan concentration on the encapsulation of eugenol using whey protein-maltodextrin conjugates," Appl. Sci., vol. 10, no. 9, May 2020, doi: 10.3390/app10093205.

76. A. R. Bilia, C. Guccione, B. Isacchi, C. Righeschi, F. Firenzuoli, and M. C. Bergonzi, "Essential oils loaded in nanosystems: A developing strategy for a successful therapeutic approach," Evidence-based Complement. Altern. Med., vol. 2014, pp. 1-14, 2014, doi: 10.1155/2014/651593.

77. F. Esmaeili et al., "Anti-inflammatory effects of eugenol nanoemulsion as a topical delivery system," Pharm. Dev. Technol., vol. 21, no. 7, pp. 887-893, 2016, doi: 10.3109/10837450.2015.1078353.

78. N. Ahmad, F. J. Ahmad, S. Bedi, S. Sharma, S. Umar, and M. A. Ansari, "A novel Nanoformulation Development of Eugenol and their treatment in inflammation and periodontitis," Saudi Pharm. J., vol. 27, no. 6, pp. 2778-790, 2019, doi: 10.1016/j.jsps.2019.04.014.

79. K. Pramod, M. R. Aji Alex, M. Singh, S. Dang, S. H. Ansari, and J. Ali, "Eugenol nanocapsule for enhanced therapeutic activity against periodontal infections," J. Drug Target., vol. 24, no. 1, pp. 24-33, 2016, doi: 10.3109/1061186X.2015.1052071.

80. A. De Araújo Lopes et al., "Eugenol as a 
promising molecule for the treatment of dermatitis: Antioxidant and anti-inflammatory activities and its nanoformulation," Oxid. Med. Cell. Longev., vol. 2018, 2018, doi: 10.1155/2018/8194849.

81. S. Woranuch and R. Yoksan, "Eugenol-loaded chitosan nanoparticles: I. Thermal stability improvement of eugenol through encapsulation," Carbohydr. Polym., vol. 96, no. 2, pp. 578-585, 2013, doi: 10.1016/j.carbpol.2012.08.117.

82. N. Ahmad, R. Ahmad, M. A. Alam, and F. J. Ahmad, "Quantification and Brain Targeting of Eugenol-Loaded Surface Modified Nanoparticles Through Intranasal Route in the Treatment of Cerebral Ischemia," Drug Res. (Stuttg)., vol. 68, no. 10, pp. 584-595, 2018, doi: 10.1055/a-0596-7288.

83. C. Gomes, R. G. Moreira, and E. Castell-Perez, "Poly (DL-lactide-co-glycolide) (PLGA) Nanoparticles with Entrapped transCinnamaldehyde and Eugenol for Antimicrobial Delivery Applications," J. Food Sci., vol. 76, no. 2, pp. 16-24, 2011, doi: 10.1111/j.17503841.2010.01985.x.

84. A. Garg and S. Singh, "Enhancement in antifungal activity of eugenol in immunosuppressed rats through lipid nanocarriers," Colloids Surfaces B Biointerfaces, vol. 87, no. 2, pp. 280-288, 2011, doi: 10.1016/j.colsurfb.2011.05.030.

85. V. B. Pokharkar, P. B. Shekhawat, V. V. Dhapte, and L. P. Mandpe, "Development and optimization of eugenol loaded nanostructured lipid carriers for periodontal delivery," Int. J. Pharm. Pharm. Sci., vol. 3, no. 4, pp. 138-143, 2011.

86. S. Gaysinsky, P. M. Davidson, B. D. Bruce, and J. Weiss, "Stability and antimicrobial efficiency of eugenol encapsulated in surfactant micelles as affected by temperature and $\mathrm{pH}$," J. Food Prot., vol. 68, no. 7, pp. 1359-1366, 2005, doi: 10.4315/0362-028X-68.7.1359.

87. N. Shahabadi, A. Akbari, F. Karampour, and M. Falsafi, "Cytotoxicity and antibacterial activities of new chemically synthesized magnetic nanoparticles containing eugenol," J. Drug Deliv. Sci. Technol., vol. 49, no. November 2018, pp. 113-122, 2019, doi: 10.1016/j.jddst.2018.11.001.

88. C. Sebaaly, A. Jraij, H. Fessi, C. Charcosset, and H. Greige-Gerges, "Preparation and characterization of clove essential oil-loaded liposomes," Food Chem., vol. 178, pp. 52-62, 2015, doi: 10.1016/j.foodchem.2015.01.067.

89. P. Jin, R. Yao, D. Qin, Q. Chen, and Q. Du, "Enhancement in Antibacterial Activities of Eugenol-Entrapped Ethosome Nanoparticles via Strengthening Its Permeability and Sustained Release," J. Agric. Food Chem., vol. 67, no. 5, pp. 1371-1380, 2019, doi: 10.1021/acs.jafc.8b06278. 